\title{
Personal Hygiene and Worm Eggs at Pupils Nail in Kupang City
}

\author{
Enni Rosida Sinaga ${ }^{1}$, Erika Maria Resi ${ }^{2}$, Wanti $^{3}$ \\ ${ }^{1,2,3}$ Health Polytechnic, Ministry of Health Kupang, Indonesia
}

\begin{tabular}{l}
\hline \hline Article Info \\
\hline Article history: \\
Received Jun 28, 2016 \\
Revised Aug 15, 2016 \\
Accepted Aug 22, 2016 \\
\hline
\end{tabular}

\section{Keyword:}

Egg Worm

Latrine Use

Personal Hygiene

Playing Habit

\begin{abstract}
Worm disease does not cause death but can affect digestion, absorption and metabolism of food. Helminthiasis figure in Kupang City in particular were not recorded properly, but when viewed from its risk factor then it was endemic because of sanitary conditions, personal hygiene, behavior, and the provision of clean water is still low. This study aim to identify the presence of worm's eggs in the pupils nail and the correlation with clean and healthy living behavior of pupils. This analytic observational study used cross sectional design. The samples were primary school students as many as 50 people that were taken by random sampling. Data collection was through interviews and laboratory tests on stool samples and analyzed by using chisquare. Results found as many as 13 pupils (26\%) were infested by worm eggsof Ascaris lumbricoides at their nail. There were no relation between the presence of worm eggs at pupils nail with gender $(\mathrm{p}=0.303)$, age $(\mathrm{p}=0.747)$, grade $(\mathrm{p}=0.643)$ and playing habits $(\mathrm{p}=1.000)$, but there is an association between the presence of worm eggs at elementary pupils nails with the latrine use $(\mathrm{p}=0.049)$ and personal hygiene $(\mathrm{p}=0.039)$. So that PHC expected to cooperate with the department of education improve the promotion and provision of facilities to support a clean and healthy behaviors for elementary school students.
\end{abstract}

Copyright $@ 2016$ Institute of Advanced Engineering and Science. All rights reserved.

\section{Corresponding Author:}

Wanti,

Health Polytechnic,

Ministry of Health Kupang,

Jl. Piet A. Tallo, Kupang, NTT Province, Indonesia.

Email: trivena78@yahoo.com

\section{INTRODUCTION}

Clean and Healthy Lifestyle Behavior (PHBS) is a set of behaviors that is practiced on the basis of awareness of the learning outcomes that make a person or family to help them selves in the field of health and play an active role in creating public health. Implementing Clean and Healthy Lifestyle Behavior useful to prevent, mitigate and protect themselves from the threat of disease as well as take advantage of quality health services, effective and efficient [1]. So that people are not susceptible to the disease and it is expected that people can work more productively and for children may increase morale and productivity of children's learning.

PHBS in school is a set of behaviors that are practiced by students, teachers, and school environment on the basis of the public consciousness as a result of learning, thus independently able to promote health, prevent disease and maintain health and play an active role in creating a healthy environment. They are also expected to help teachers and health workers at the time of the health services in schools. ${ }^{1}$ Soil Transmitted Helminthes (STHs) Prevalence according to the WHO, in 2006 remain high at a loss and impact on human. Worm infection does not cause sudden death but can affect income, digestion, absorption and metabolism of food. Besides being able to inhibit the development of physical, intellectual, mental, achievements, may lower endurance, so susceptible to other diseases [2]. 
The prevalence of STHs are often found in children is Ascaris lumbricoides, Trichuris trichiura and Hookworm. Based on WHO in 2006, said that the prevalence of worm infection in the world are still high that 1 billion people are infected with Ascaris lumbricoides, 795 million people are infected with Trichuris trichiura and 740 million people are infected with hookworm [2].

Worm infection figures in NTT Province are not recorded properly, but when viewed from the risk factor such as sanitation, personal hygiene, behavior, and the provision of clean water is still low, it can be predicted that worm disease is endemic in NTT. Based on that condition, this research would like to obtain information about a clean and healthy life behavior and the presence of worm eggs in the nails of pupils.

\section{RESEARCH METHOD}

This study is analytic observational study with cross sectional design. The study was conducted in June to November 2014. The population are all elementary school students in Kupang City, while the sample are students in SDN Naimata as many as 50 people were taken by random sampling technique.

Research variables are the presence of worm eggs in the nail of school children, sex, age, grade, use of latrines, personal hygiene and playing habits. Data were collected with regard anonymity and confidentiality through interviews using questionnaires and laboratory tests on stool samples to detect the presence of worm's eggs and the worm species in the nail of elementary school students Naimata. The collected data was then processed through the stages of editing, coding, entry, cleaning and tabulating, then analyzed using the chi-square test with $\alpha=0.05$ to see relationships between the presence of worm eggs on the nail with a clean and healthy living behavior of elementary school students.

\section{RESULTS AND DISCUSSION}

\subsection{Results}

This study found the presence of worm eggs in nail school students is $26 \%$ from the 50 students who examined her nails, and all are Ascaris lumbriocoides. The proportion of the presence of worm eggs at the nails of students is more common in women (30.6\%), students aged $\leq 10$ years $(29.6 \%)$, grade $1-3(33.3 \%)$, the bad use of latrines $(75 \%)$, the bad personal hygiene $(35.3 \%)$ and the bad playing habits $(27.1 \%)$, as shown in Table 1.

Table 1. Distribution of Worm Eggs Based on Independent Variables an the Nail of Naimata Primary School Students in Kupang City

\begin{tabular}{llcccccc}
\hline & \multirow{2}{*}{ Research Variables } & \multicolumn{2}{c}{$(-)$ Worm Eggs } & \multicolumn{2}{c}{$(+)$ Worm Eggs } & \multicolumn{2}{c}{ Total } \\
& & $\mathrm{N}$ & $\%$ & $\mathrm{~N}$ & $\%$ & $\mathrm{~N}$ & $\%$ \\
\hline \multirow{2}{*}{ Sex } & Female & 25 & 69.4 & 11 & 30.6 & 36 & 100 \\
\multirow{4}{*}{ Age } & Male & 12 & 85.7 & 2 & 14.3 & 14 & 100 \\
& $>10$ year & 18 & 78.3 & 5 & 21.7 & 23 & 100 \\
Grade & $\leq 10$ year & 19 & 70.4 & 8 & 29.6 & 27 & 100 \\
& Kelas 4-6 & 33 & 75.0 & 11 & 25.0 & 44 & 100 \\
Latrine Use & Kelas 1-3 & 4 & 66.7 & 2 & 33.3 & 6 & 100 \\
\multirow{4}{*}{ Personal Hygiene } & Good & 36 & 78.3 & 10 & 21.7 & 46 & 100 \\
& Not Good & 1 & 25.0 & 3 & 75.0 & 50 & 100 \\
\multirow{4}{*}{ Playing Habit } & Good & 15 & 93.8 & 1 & 6.2 & 16 & 100 \\
& Not Good & 22 & 64.7 & 12 & 35.3 & 34 & 100 \\
& Good & 2 & 100 & 0 & 0 & 2 & 100 \\
& Not Good & 35 & 72.9 & 13 & 27.1 & 48 & 100 \\
\hline
\end{tabular}

Based on Chi-Square test was not all study variables associated with the presence of worm eggs on the nails of students and related variables were latrine use ( $p=0.040$ and OR 10.800) and personal hygiene $(\mathrm{p}=0.039$ and OR 8.182), as shown in Table 2 . 
Table 2. The Relation between Personal Hygiene and the Presence of Worm Eggs on the Nail of Naimata Primary School Students in Kupang City

\begin{tabular}{llccc}
\hline \multicolumn{2}{c}{ Research Variables } & OR & $P$ & CI 95\% \\
\hline Sex & $\begin{array}{l}\text { Female } \\
\text { Male }\end{array}$ & 0.379 & 0.303 & $0.072-1.985$ \\
Gre & $\begin{array}{l}>10 \text { year } \\
\leq 10 \text { year }\end{array}$ & 1.516 & 0.747 & $0.417-5.506$ \\
Grade & $\begin{array}{l}\text { Grade 4-6 } \\
\text { Grade 1-3 } \\
\text { Good } \\
\text { Latrine Use }\end{array}$ & 1.500 & 0.643 & $0.241-9.345$ \\
Personal Hygiene & $\begin{array}{l}\text { Not Good } \\
\text { Good } \\
\text { Not Good } \\
\text { Good } \\
\text { Not Good }\end{array}$ & 10.800 & 0.049 & $1.010-115.432$ \\
Playing Habit & 8.182 & 0.039 & $0.960-69.747$ \\
\hline
\end{tabular}

\subsection{Discussion}

This research find amount $26 \%$ of 50 primary school students in Naimata are positive of worm eggs at their nails and all $(100 \%)$ are Ascaris lumbricoides. This percentage is higher than the results of previous studies, namely $5.20 \%$ in Tapanuli [3], and $10.7 \%$ in Semarang [4]. But the numbers in this study are smaller than study in makasar ie $90.7 \%$ of elementary students infected with worms ascariasis and trichuriasis, and as a result as many as 53\% have anemia [5], and also study in makasar showed $60 \%$ elementary students were infested by worm [6]. Study in Imo State Nigeria and Ethiopia also found higher number of students were infected by soil transmitted helminthic (STH), respectively 30.3\% and 41.7\% [7],[8], with two kind of helminths that are A. lumbricoides (19.8\%) and T. trichiura (15.6\%) [8].

Not all variables in this study relates to the presence of worm eggs on the nail, which is related is the use of latrines, and personal hygiene, while the variables of gender, age, class, and a habit of playing does not relate to the presence of worm eggs on the nail. The same study with previous research that there was no relationship between age and grade with the incidence of intestinal worms [9], which in this study p-value for the age class of 0.747 and 0.643 . In other hand, the prevalence of (STH) infection by sex in Nigeria was different significantly $(\mathrm{p}=0.001)$ [7].

Although based on a previous study no correlation between the cleanliness of nails with a prevalence of worm infection on elementary school students $(\mathrm{p}=0.632)$, but the presence of worm eggs on the nails students is quite high in this study remains to be an important concern, as most likely also find worms in the digestive tract when it is not supported by good clean and healthy behavior [9]. The presence of eggs worm at nails is important factor for STH infection, and based on previous study that habit of hand washing after toilet was predictor of STH infection [8].

The playing habit in this study as many as $96 \%$ are not well and all the positive nail students with worm eggs are the pupil who has a bad playing habit. There are still many students who are playing on ground without barefoot and do not wash their hands with soap when you're done playing. Statistically these conditions showed no association between the playing habit with the presence of worm eggs at the nail with a value of $\mathrm{p}=1.000$. This is similar to a previous study in Karangroto that there was no relationship playing habit with the presence of worms in children aged 1-4 years with $p=1.000$ [10]. Similarly, research by Sofiana found no relationship between wearing footwear when playing outdoors with wormy infestation with $\mathrm{p}=0.909$ [11].

Based on the chi-square test, this study find an association between the use of latrines and worm infestation in the nail with a $\mathrm{p}$ value $=0.049$ and $\mathrm{OR}=10.8$. This means that the students with the bad use of latrines have the possibility of finding the worm eggs on the nails 10.8 times greater than the students with good use latrine. Previous research found that latrine ownership and latrine type were not related to worm infestation in children 1-4 years old; this is because the latrine ownership does not always determine the use of latrines [7],[10]. This can happen if the students who do not have latrine have good personal hygiene so as to prevent worm infestation, and vice versa although students has latrine but their personal hygiene is poor then remain risk of worm infestation.

According Notoatmodjo, to avoid the spread of disease through fecal including intestinal worms and other digestive diseases then everyone should use latrine as a container of stool [12]. Latrines need to be managed well because of human feces contain protozoa, worm eggs, which is the source of virus diseases, especially diarrhea agent. Latrines should be closed, so the flies as vector diseases can not fly and perch on stool. The construction of latines also should be strong, sloped to avoid puddles on the floor and the water source should be far away from the latrines or more than 10 meters and it depends on the porosity of the soil in that area [1]. 
Someone who does not wear a pit latrine can keep either a neighbor or a public toilet. Someone using the toilet for defecation will not necessarily free worm infestation, because even use toilet for defecation but if the latrine condition is not good or the way he use latrine is not good then it is still possible for someone contaminated with the germs and worm in the feces. As in this study that there is a $100 \%$ latrine in students house, $100 \%$ defecate in latrines, but there are still students who do not wash their hands with soap after defecating, they are also not flush the stool until it is clean. This condition causes despite being $100 \%$ defecate in latrines but allow students still at risk for infection germs or worms of faeces, especially on the hands or nails. This is similar to previous research that defecate in latrines is not related $(\mathrm{p}=0.744)$ with wormy infestation in students in Kalibening Salatiga [11], but latrine sanitation has a relationship with worm infestation with OR 16,35, it means that better condition of latrine will reduced possibility for student to infected by worms [6]. Eventhough defecate in latrine is not related with the STH infection [11], but open defecation significantly as an important risk factor of STH infection [13].

The study also find $68 \%$ of elementary students of Naimata have bad personal hygiene and as much as $92.3 \%$ of them are positive worm eggs and based on chi square test both variables have significant relationship. The previous study also found that bad personal hygiene will increase risk of students to worm infestation by 6 times [6]. Poor personal hygiene is a reflection of the environmental conditions and the behavior of individuals who are not healthy and low personal hygiene is more likely affected by worm infections [14],[15]. This is in contrast with previous research by Febriani, namely Ascaris lumbricoides infestation more common in students who have good personal hygiene (83.3\%) [16].

Worms infect humans can penetrate human skin by larvae infectious or swallowing worm eggs are sticky on the food and drink that is not thoroughly cooked or swallowing worm eggs are sticky on your nails and hands that are not washed well before eating [17]. Therefore, food and drink should be cooked thoroughly correct, also nails and hands should be cleaned by soap before eating or dringking. Better personal hygiene is not only for children but also for parents and food handler at school, because it is posible that parents who responsible for takecare children at home and food handler at school also infected by helminth, and previous study found that as many as $92 \%$ of food handler at school were positive with fecal oral parasite in their stool [18]. The prevention of STH infection by Albendazole also need to be done because it can prevent the infection $(\mathrm{p}<0.01)$ [14] and also reduce the infection $94.4 \%$ for A. lumbricoides, $49.7 \%$ for T. trichiura and $90.2 \%$ for hookworm [19].

\section{CONCLUSION}

This study find a nail with worm eggs in elementary school student as many as $26 \%$ and all are Ascaris lumbricoides. There is no relation the presence of worm's eggs on primary school pupils nail with gender $(\mathrm{p}=0.303)$, age $(\mathrm{p}=0.747)$, grade $(\mathrm{p}=0.643)$ and playing habits $(\mathrm{p}=1.000)$, but there is an association between the presence of worm eggs on nails elementary school student with latrine use $(p=0.049)$ and personal hygiene $(\mathrm{p}=0.039)$. The use of latrines families who do not qualify can be at risk for disease transmission and intestinal worms, as well as to personal hygiene also plays a role in the occurrence of worm eggs. PHC expected to cooperate with the department of education improve the promotion and provision of facilities to support a clean and healthy behaviors for elementary school students.

\section{ACKNOWLEDGEMENTS}

Many thanks to Director of Health Polytechnic MoH Kupang for financial supporting, Head of Naimata Elementary School, teachers and students for the permission and collaboration along the study, and for Head of Provincial Health Laboratory and staffs for laboratory assistance.

\section{REFERENCES}

[1] MoH RI, "General Guidelines for National Programme Combating Worms in the Age of Decentralization," Jakarta, MOH RI, 2004.

[2] WHO, "Soil Transmitted Helminths," Geneva, WHO, 2006.

[3] L. Sitompul, "Consumption description Fruit Pinang, Genesis Helminthiases and Nutritional Status of 175750 students in elementary Nainggolan Pardamean Village District of North Tapanuli Pahae Jae 2013," Thesis, FKM USU, Medan, 2013.

[4] A. H. Texanto, "The Relationship between the Hygiene Status Individuals with Genesis Figure Soil Transmitted Helminths Infections in SDN 03 Pringapus, Semarang regency, Central Java,” Thesis, FK UNDIP, Semarang, 2008.

[5] I. A. Ibrahim, "Ascariasis and Trichuriasis as Determinants of Nutritional Anemia on Elementary School Students in Urban Slums Makasar,” Food Nutrient Media, vol/issue: 13(1), 2012. 
[6] J. Fitri, Z. Saam, M. Y. Hamidy, "Analysis of Risk Factors Worm Infection Primary School Students in Eastern District Angkola Timur, Tapanuli South District in 2012," Jurnal Environment Science, vol/issue: 6(2), pp. 146$161,2012$.

[7] K. L. Odinaka, E. C. Nwolisa, F. Mbanefo, A. C. Iheakaram, S. Okolo, "Prevalence and Pattern of Soil-Transmitted Hemlinthic Infection among Primary School Children in a Rural Community in Imo State, Nigeria", J Trop Med, vol. 4, 2015.

[8] D. Emana, K. Jemal, M. Bajiro, Z. Mekonen, "Prevalence and Intensity of Soil-Transmitted Helminths Among School-Aged Children in Sigmo Primary School, Jimma Zone, South-Western Ethiopia", Clinic Med Res, vol/issue: 4(4), pp. 98-103, 2015

[9] K. Faridan, L. Marlinae, N. A. Audha, "Factors Correlated with Helminthiasis Incidence on Students of Cempaka 1 Elementary School Banjarbaru," Jurnal Buski, vol/issue: 4(3), pp. 121-127, 2013.

[10] Endriani, Mifbakhudin, Sayono, "Some of the Factors Associated with Helminthiases Prevalence in Childhood 1-4 Years," J Kesehat Masy Indones, vol/issue: 7(1), pp. 22-35, 2011.

[11] L. Sofiana, "Behavior Relationships with Soil Transmitted Helminths Infection in Primary School Children MI Principles of Islam Kalibening, Salatiga," J Kesehat Masy Indones, vol/issue: 4(2), pp. 112-143, 2010.

[12] S. Notoatmodjo, "Education and Health Behavior," Ed. Rev, Jakarta, Rineka Cipta, 2003.

[13] D. Kattula, R. Sarkar, S. S. R. Ajjampur, S. Minz, B. Levecke, J. Muliyil, G. Kang, "Prevalence and Risk Factors for Soil Transmitted Helminth Infection among School Children in South India," Indian J Med Res, vol. 139, pp. 76-82, 2014

[14] H. Ganda, "Parasitology of Medicine," Jakarta, FKUI, 2003.

[15] D. M. Damanik, Soeyoko, A. H. Husodo, "Sanitation of House and School, Personal Hygiene and Infection of Soil Transmitted Helminths (STH) among Elementary School Students," IJPHS, vol/issue: 3(1), pp. 43-50, 2014.

[16] W. N. Febriani, "Soil Transmitted Infection Prevalence of helminths in Government Elementary School Pupil Islamiyah in Simbang Wetan Village Subdistrict Buaran Pekalongan,” Thesis, FK UNDIP, Semarang, 2012.

[17] Sandjaja, "Protozoology of Medicine," Surabaya, FK UNAIR, 2007.

[18] Idowu O. A., Rowland S. A., "Oral Fecal Parasites and Personal Hygiene of Food Handlers in Abeokuta, Nigeria," African Health Sciences, vol/issue: 6(3), pp. 160-164, 2006.

[19] F. Oyewole, F. Ariyo, A. Sanyaolu, W. A. Oyibo, T. Fameya, P. Monye, M. Ukpong, C. Okoro, "Intestinal Helminthiases and Their Control with Albendazole among Primary School Children in Riverine Community of Ondo State, Nigeria," Southeast Asian J Trop Med Public Health, vol/issue: 33(2), pp. 214-217, 2002. 